\title{
Combination of lidocaine/prilocaine with tramadol for short time anaesthesia-analgesia in chelonians: 18 cases
}

\author{
Filippo Spadola ${ }^{1}$, Manuel Morici ${ }^{1}, Z_{\text {deněk Knotek }}^{2}$ \\ ${ }^{1}$ University of Messina, Department of Veterinary Science, \\ Messina, Italy \\ ${ }^{2}$ University of Veterinary and Pharmaceutical Sciences Brno, Faculty of Veterinary Medicine, \\ Avian and Exotic Animal Clinic, Czech Republic
}

Received July 3, 2014

Accepted October 22, 2014

\begin{abstract}
The aim of this study was the evaluation of the practical use of lidocaine/prilocaine cream as the local anaesthetic in combination with tramadol anaesthesia for the surgical treatment of prolapsed penis in chelonians. Eighteen animals were included in this study. After administration of tramadol, prolapsed penis was cleaned and disinfected. Lidocaine/prilocaine cream at a dose of $1 \mathrm{~g} / 10 \mathrm{~cm}^{2}$ was applied on the penile mucosa. The time interval from lidocaine/prilocaine application to a loss of hind limb withdrawal reflex and the response to penile mucosa pinching was recorded as the induction time for surgical anaesthesia. The time interval from lidocaine/ prilocaine application to full restoration of tail and hind limb withdrawal reflex was recorded as the recovery time. In two male chelonians the response to pain stimuli persisted for more than $20 \mathrm{~min}$ after lidocaine/prilocaine cream application, and the anaesthetic cream had to be re-administered. After this second application of lidocaine/prilocaine cream, surgical anaesthesia was reached within 28 and $32 \mathrm{~min}$. The mean induction time for surgical anaesthesia was $19.22 \pm 4.36 \mathrm{~min}$. The mean recovery time was $40.83 \pm 7.68 \mathrm{~min}$. In all 18 male chelonians the surgical treatment of prolapsed penile was uneventful. Topical application of lidocaine/prilocaine cream can be used as a feasible form of local anaesthesia in combination with tramadol analgesia management for minor surgical procedures in chelonians.
\end{abstract}

Reptiles, terrapins and tortoises, pain, minor surgery

Surgical treatment of penile (phallus) prolapse is a common procedure in veterinary practice with captive male chelonians (Raiti 1995; Barten 2006). It has been reported as a sequel to constipation and neurological dysfunction. Prolapse of the penis (or protrusion of the penis for an extended period of time; Bradley 2000) can be a consequence of inflammation of the mucosa of the penis and/or cloaca (cloacitis), a metabolic disease (calcium deficiency), or congenital anomalies (Bennett 1998a; Bradley 2000; Harkewicz 2002; Johnson-Delaney 2012). Prolapsed mucosa becomes quickly hyperaemic and oedematous. Consequent bacterial infections lead to a necrotic/gangrenous inflammation and consequent septicaemia may even cause the death of the patient (Frye 1991). Standard treatment of penile prolapse starts with gentle cleaning of the debris off the mucosal surface and reduction of the volume of swollen tissues. Then a minor surgical approach can be used: mechanical replacement of the penis into the cloaca, or penile amputation. Decision is made according to tissue viability of the prolapsed organ (Rosskopf et al. 1982; Harkewitz 2002; Hernandez-Divers 2004). Surgery has to be performed with the use of an effective form of anaesthesia and analgesia (Barten 2006). Local anaesthesia with lidocaine or procaine for topical anaesthesia in reptiles has been well documented (Schumacher 1996; Bennett 1998b). In conjunction with a suitable agent of general anaesthesia, local anaesthesia was used for minor surgical procedures (Schumacher and Yelen 2006; Schumacher 2007; Gibbons and Klaphake 2013).

Address for correspondence:

Prof. MVDr. Zdeněk Knotek, CSc. Dip ECZM (herpetology)

Avian and Exotic Animal Clinic

Faculty of Veterinary Medicine

University of Veterinary and Pharmaceutical Sciences Brno

Palackého třída 1/3, 61242 Brno, Czech Republic 
Medical cream EMLA $^{\circledR}$, an emulsion mixture that contains $25 \mathrm{mg}$ of lidocaine and $25 \mathrm{mg}$ of prilocaine in one gram, has been used successfully for topical anaesthesia on skin and mucosae in human and veterinary medicine. Lidocaine and prilocaine stabilize the neuronal membranes inhibiting the flow of natrium ions. In the area of its application EMLA $^{\circledR}$ induces a biphasic vascular response, when initial vasoconstriction is followed by vasodilation. In human medical practice, $\mathrm{EMLA}^{\circledR}$ is administered topically $1-2 \mathrm{~h}$ before surgery, and the effect lasts for $2 \mathrm{~h}$ after removal of the occlusive dressing. The absorption of EMLA ${ }^{\circledR}$ by genital mucosa is very rapid (Ehrenström-Reiz and Reiz 1982) which has been tested with excellent results in minor surgeries (Brough et al. 1995; Taddio et al. 1997; Gyftopoulos 2012). Several trials with EMLA $^{\circledR}$ have been conducted in dogs, cats, rabbits, and rats (Flecknell et al. 1990; Wagner et al. 2006; Longley 2008). However, almost half of the frogs exposed to combination of lidocaine with prilocaine did not recover and died (Guenette and Lair 2003). Redrobe (2004) suggested the practical use of EMLA ${ }^{\circledR}$ applied to reptile skin prior to intravenous injection or catheter placement.

The aim of this study was to evaluate the practical use of lidocaine/prilocaine cream as the local anaesthetics in combination with tramadol for the surgical treatment of prolapsed penis in chelonians.

Animals

\section{Materials and Methods}

The group of male chelonians included in this study consisted of 14 animals with acute penile prolapse: 6 Hermann's tortoises (Testudo hermanni), 3 yellow-bellied terrapins (Trachemys scripta scripta), 2 red-eared terrapins (Trachemys scripta elegans), 1 adult African helmeted turtle (Pelomedusa subrufa; Plate III, Fig. 1), 1 leopard tortoise (Stigmochelys pardalis), 1 Mississippi map turtle (Graptemys pseudogeographica kohnii), and 4 animals with chronic penile prolapse: 3 Hermann's tortoises (Testudo hermanni), and 1 yellow-bellied terrapins (Trachemys scripta scripta).

\section{Anaesthesia}

For pain management tramadol (Altadol, Formevet, Italy) at a dosage of $10 \mathrm{mg} / \mathrm{kg}$ was orally administered to the patient $30 \mathrm{~min}$ before anaesthetic cream application. The patient was manually restrained and placed on an electric heating pad kept at $37.5^{\circ} \mathrm{C}$. The prolapsed penis was gently cleaned with saline $(0.9 \% \mathrm{NaCl}, \mathrm{S} . \mathrm{A} . \mathrm{L}$.F. $\mathrm{SpA}$, Italy) to wash out all the debris and disinfected with $0.05 \%$ povidone-iodine $\left(7.5 \%\right.$ Betadine ${ }^{\circledR}$, Mundipharma AG, Switzerland). Lidocaine/prilocaine cream (EMLA ${ }^{\circledR}$ cream 5\%, AstraZeneca SpA, Milan, Italy) at a dose of $1 \mathrm{~g} / 10 \mathrm{~cm}^{2}$ was applied on the penile mucosa (Plate III, Fig. 2). Selected clinical indicators were continuously recorded including the loss of the tail and hind limb withdrawal reflex, the loss of response to pinching the mucosa of the prolapsed penis with forceps, and the restoration of the tail and hind limb withdrawal reflex. The time interval from lidocaine/prilocaine application to the loss of the hind limb withdrawal reflex, and the response to penile mucosa pinching was recorded as the induction time for surgical anaesthesia; the time interval from lidocaine/prilocaine application to the full restoration of the tail and hind limb withdrawal reflex was recorded as the recovery time.

\section{Surgery}

When surgical anaesthesia was reached, the prolapsed penis was clamped near its base with haemostat forceps and 2-3 ligations with absorbable suturing material (Vicryl 4-0, Johnson and Johnson) were placed at the base of the penis. The prolapsed engorged organ was transected with Metzenbaum scissors or scalpel blade distally to the sutures. Antibiotic ointment with tobramycin $\left(0.3 \%\right.$ Tobral $^{\circledR}$, Alcon, Milan, Italy) was applied topically on the penile stump. After surgery patients received $5 \mathrm{mg} / \mathrm{kg}$ of tramadol administered orally.

\section{Results}

In two male Hermann's tortoises the response to pain stimuli persisted for more than $20 \mathrm{~min}$ after lidocaine/prilocaine cream application and anaesthetic cream had to be re-administered. After this second application of lidocaine/prilocaine cream, surgical anaesthesia was reached within 28 and $32 \mathrm{~min}$, respectively (Table 1). After topical application of lidocaine/prilocaine cream on the penile mucosa, surgical anaesthesia was reached within $19.22 \pm 4.36 \mathrm{~min}$. Full recovery of the tail and hind limb withdrawal reflex and the full response to pinching was recorded at $40.83 \pm 7.68 \mathrm{~min}$ after 
Table 1. Anaesthesia with tramadol and lidocaine/prilocaine in male chelonians.

\begin{tabular}{lccc}
\hline Species & Body weight $(\mathrm{kg})$ & $\begin{array}{c}\text { Induction time for } \\
\text { surgical anaesthesia (minutes) }\end{array}$ & $\begin{array}{c}\text { Recovery time } \\
\text { (minutes) }\end{array}$ \\
\hline Trachemys scriptas cripta & 0.33 & 15 & 30 \\
Trachemys scripta elegans & 0.23 & 16 & 34 \\
Trachemys scripta scripta & 0.32 & 18 & 36 \\
Testudo hermanni & 0.36 & 19 & 38 \\
Pelomedusa subrufa & 0.26 & 17 & 47 \\
Trachemys scripta elegans & 0.37 & 16 & 32 \\
Testudo hermanni & 0.41 & 20 & 44 \\
Testudo hermanni & 0.52 & 19 & 52 \\
Testudo hermanni & 0.40 & 28 & 42 \\
Testudo hermanni & 0.36 & 20 & 35 \\
Testudo hermanni & * & 32 & 41 \\
Testudo hermanni & 0.37 & 20 & 46 \\
Trachemys scripta scripta & 0.66 & 18 & 42 \\
Graptemys pseudogeographica kohnii & 0.22 & 16 & 29 \\
Trachemys scripta scripta & 0.16 & 15 & 43 \\
Testudo hermanni & 0.22 & 17 & 37 \\
Stigmochelys pardalis & 0.51 & 20 & 61 \\
Testudo hermanni & 10.2 & 20 & 46 \\
\hline Mean & 0.62 & 19.22 & 40.83 \\
SD & 0.941 & 4.36 & 7.68 \\
Minimum & 2.329 & 15 & 30 \\
Maximum & 0.15 & 32 & 61 \\
\hline
\end{tabular}

"In two Hermann's tortoises the lidocaine/prilocaine cream had to be re-administered.

lidocaine/prilocaine application. In all 18 male chelonians the surgical treatment of prolapsed penis was uneventful as checked on two follow-up days ( 7 and 30 days after surgery).

\section{Discussion}

Results of this study demonstrate the topical treatment with lidocaine/prilocaine cream as a feasible form of local anaesthesia for the surgical treatment of prolapsed penis in chelonians. A number of other anaesthetic protocols for penile/cloacal surgery in chelonians were published (Raiti 1995; Harkewicz 2002; Barten 2006), including local anaesthesia (Mans et al. 2011a, b; 2013; Rivera et al. 2011). Administration of $2 \%$ lidocaine into the intrathecal space at the level of the proximal coccygeal vertebrae proved to be a feasible and effective technique for induction of spinal anaesthesia in chelonians. Complete motor block of the cloacal sphincter, tail and hind limbs was induced in $57-83 \%$ of all terrapins after one or two injections. The mean onset time and duration of complete motor block of the hind limbs, tail and cloaca were $2.8 \pm 3$ and $76 \pm 46 \mathrm{~min}$, respectively (Mans et al. $2011 \mathrm{a}, \mathrm{b} ; 2013)$. However, intrathecal administration is a special technique which needs practical experience. The method of topical anaesthesia with lidocaine/prilocaine cream is safe for the chelonian patient and easy for the clinician. Results of this study showed that the combination of oral tramadol analgesia management with topical application of lidocaine/prilocaine cream on the mucosa is a feasible method of surgical anaesthesia for male chelonian patients with penile prolapse. 


\section{Acknowledgements}

The project received partial funding from the Faculty of Veterinary Medicine of the University of Veterinary and Pharmaceutical Sciences, Brno (Institucionální výzkum FVL-2014).

\section{References}

Barten SL 2006: Penile prolapse. In Mader DR (Ed.): Reptile Medicine and Surgery, $2^{\text {nd }}$ edn., WB Saunders Company, St. Luis, Missouri, pp. 862-864

Bradley T 2000: Plastron osteotomy and intestinal foreign body removal in an African spur thighed tortoise (Geochelone sulcata). In: Proceedings of the $7^{\text {th }}$ Annual Association of Reptilian Amphibian Veterinarians Conference, Reno, Nevada, pp. 155-157

Bennett RA 1998a: Management of common reptile emergencies. In: Proceedings of the $4^{\text {th }}$ Annual Association of Reptilian Amphibian Veterinarians Conference, Kansas City, pp. 67-72

Bennett RA 1998b: Clinical, diagnostic, and therapeutic techniques. In: Proceedings of the $4^{\text {th }}$ Annual Association of Reptilian Amphibian Veterinarians Conference, Kansas City, pp. 35-40

Brough RJ, Betts CD, Payne SR 1995: EMLA® cream anaesthesia for frenuloplasty. Brit J Urol 76: 653-654

Ehrenström-Reiz GME, Reiz SLA 1982: EMLA ${ }^{\circledR}$-a eutectic mixture of local anaesthetics for topical anaesthesia. Acta Anaesth Scand 26: 596-598

Flecknell PA, Liles JH, Williamson HA 1990: The use of lidocaine-prilocaine local anaesthetic cream for painfree venepuncture in laboratory animals. Lab Anim 24: 142-146

Frye FL 1991: Reproduction. In Frye FL (Ed.): Reptiles Biomedical and Surgical Aspects of Captive Reptile Husbandry, $2^{\text {nd }}$ edn., Krieger Publishing Company, Florida, pp. 345-392

Gibbons PM, Klaphake E 2013: Reptiles. In: Carpenter JW (Ed.): Exotic Animal Formulary, $4^{\text {th }}$ edn, Elsevier Saunders, St. Luis Missouri, pp. 103-113

Guenette S, Lair S 2003: Comparison of different anaesthetic agents in the leopard frog (Rana pipiens): a preliminary report. In: Proceedings of the Association of Reptilian Amphibian Veterinarians Conference, Minneapolis, pp. 68-71

Gyftopoulos KI 2012: The efficacy and safety of topical EMLA $®$ cream application for minor surgery of the adult penis. Urol Ann 4: 145-149

Harkewicz KA 2002: Prolapse of the penis in a pair of cojoined twin male Hermann's tortoises (Testudo hermanni spp.). In: Proceedings of the Association of Reptilian Amphibian Veterinarians Conference, Reno, $99 \mathrm{p}$.

Hernandez-Divers SJ 2004: Surgery: principles and techniques. In: Girling JS, Raiti P (Eds.): BSAVA Manual of reptiles, $2^{\text {nd }}$ edn., BSAVA, Quedgeley, pp. 147-167

Johnson-Delaney CA 2012: Reptile dysfunction: When it has been more than four hours. In: Proceedings of the Association of Reptilian Amphibian Veterinarians, Oakland, California, 99 p.

Longley L 2008: Anaesthesia of exotic pets. Saunders Elsevier, New York, 314 p.

Mans C, Lahner LL, Steagall P, Johnson SM, Sladky KK 2011a: Intrathecal anaesthesia and analgesia in redeared slide turtles (Trachemys scripta elegans). In: Proceedings of the Association of Reptilian Amphibian Veterinarians, Seattle, $166 \mathrm{p}$.

Mans C, Lahner LL, Steagall P, Johnson SM, Sladky KK 2013: Feasibility, efficacy and inter-operator variability of spinal anaesthesia in female red-eared slide turtles (Trachemys scripta elegans). In: Proceedings of the $1^{\text {st }}$ International Conference on Avian, Herpetological and Exotic Mammal Medicine, Germany, Wiesbaden, $162 \mathrm{p}$.

Mans C, Steagall P, Lahner LL, Johnson SM, Sladky KK 2011b: Efficacy of intrathecal lidocaine, bupivacaine, and morphine for spinal anaesthesia and analgesia in red-eared slider turtles (Trachemys scripta elegans). In: Proceedings of the $43^{\text {rd }}$ Annual Conference of the American Association of Zoo Veterinarians, Kansas City, 135

Raiti P 1995: Reproductive problems of reptiles. In: Proceedings of the Association of Reptilian Amphibian Veterinarians, Sacramento, pp. 101-105

Redrobe S 2004: Anaesthesia and analgesia. In: Girling JS, Raiti P (Eds): BSAVA Manual of reptiles, $2^{\text {nd }}$ edn. BSAVA, Quedgeley, 131-146

Rivera S, Divers SJ, Knafo SE, Martinez P, Capot LJ, Tapia-Aguilera W, Flanagan J 2011: Sterilisation of hybrid Galapagos tortoises (Geochelone nigra) for island restoration. Part 2: phallectomy of males under intrathecal anaesthesia with lidocaine. Vet Rec 168: 78

Rosskopf WJ, Woerpel RW, Pitts BJ 1982: Paraphimosis in a California desert tortoise. Calif. Vet. 361: 29-30

Schumacher J 1996: Reptiles and amphibians. In: Thurman JC, Tranquilli WJ, Benson GJ (Eds): Lumb and Jones Veterinary Anesthesia. $3^{\text {rd }}$ edn. Blackwell Publishing, Iowa, USA, pp. 670-685

Schumacher J, Yelen T 2006: Anaesthesia and Analgesia. In Mader DR (Ed.): Reptile Medicine and Surgery, $2^{\text {nd }}$ edn., WB Saunders Company, St. Luis, Missouri, pp. 442-452

Schumacher J 2007: Chelonians (turtles, tortoises, and terrapins). In West G, Heard D, Caulkett N (Eds): Zoo Animal and Wildlife Immobilization and Anaesthesia. Blackwell Publishing, Iowa, USA, pp. 259-266

Taddio A, Stevens B, Craig K, Rastogi P, Ben-David S, Shennan A, Mulligan P, Koren G 1997: Efficacy and safety of lidocaine-prilocaine cream for pain during circumcision. New Engl J Med 336: 1197-201 
Wagner KA, Gibbon KJ, Strom TL, Kurian JR, Trepanier LA 2006: Adverse effects of EMLA® (lidocaine/ prilocaine) cream and efficacy for the placement of jugular catheters in hospitalized cats. J Feline Med Surg 8: $141-144$ 
Plate III

Spadola F. et al.: Combination of ... pp. 71-75

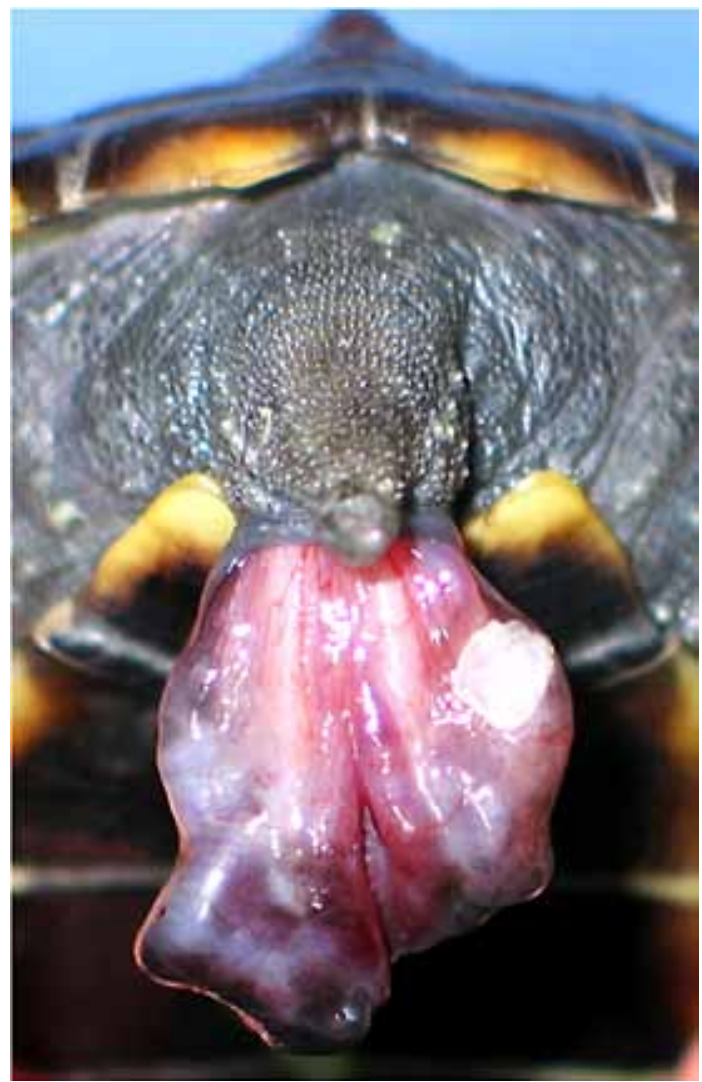

Fig. 1. Penile prolapse in an African helmeted terrapin (Pelomedusa subrufa)

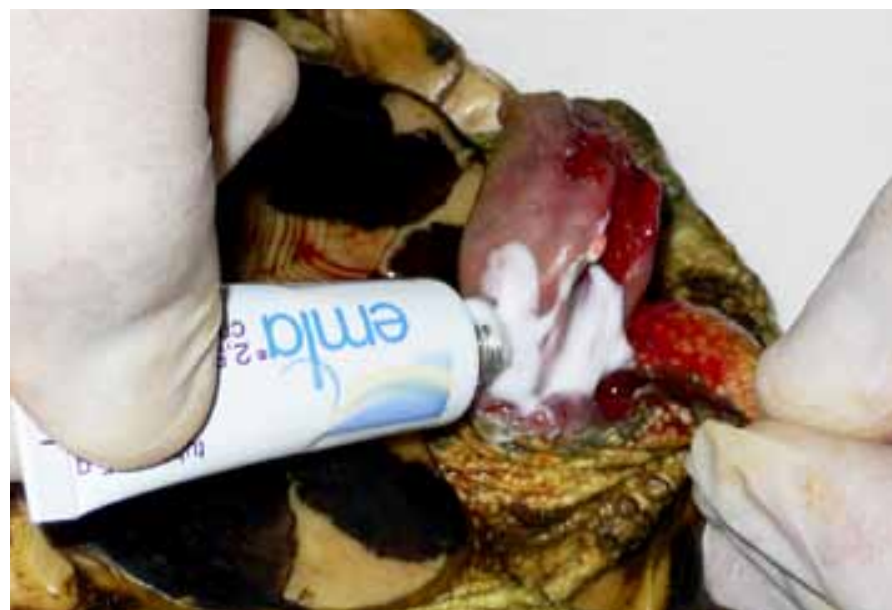

Fig. 2. Lidocaine/prilocaine cream application on penile mucosa of Hermann's tortoise (Testudo hermanni) 